\title{
What drives Web 2.0 adoption in South African civil society organisations
}

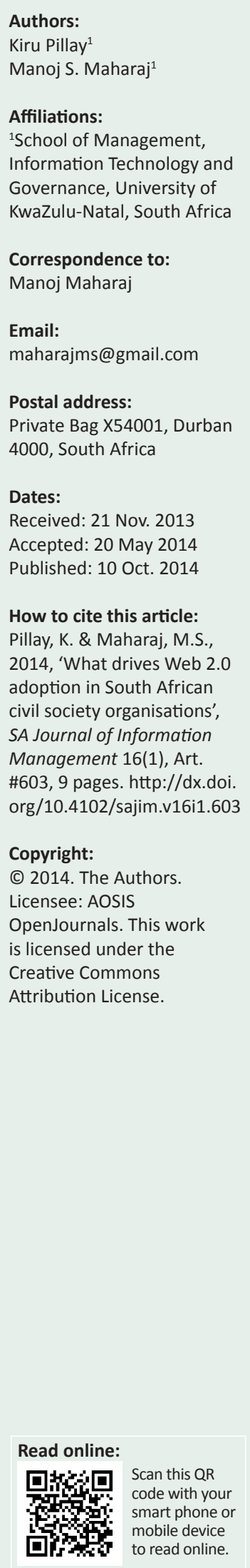

Background: The impact and consequences of social media adoption on society are only just being realised and studied in detail; consequently, there is no universal agreement as to the reasons for the adoption of these services. Even understanding why some social media services are popular remains to some extent elusive. The practical use of Web 2.0 does not provide any answers either with, for example, a noticeable difference in the way social media was strategically used by Barack Obama and Mitch Romney in the lead-up to the 2009 American elections. However, recent studies that have focused on social media adoption within specific sectors have begun to shed some light on these emerging adoption patterns; two studies in particular are illustrative: a 2012 study on the newspaper sector and a study on social media adoption and e-government.

Objectives: This study investigates why South African civil society organisations (CSOs) adopt Web 2.0 services and the perceived and actual benefits of such adoption.

Method: A survey questionnaire was sent to 1712 South African CSOs listed in the Prodder database to explore why certain social media services were adopted and the perceived benefits thereof.

Results: Internal reasons for the adoption of social media services by South African CSOs coalesce around organisational visibility and access to information. External reasons focus on organisations needing to become more relevant and more connected to like-minded organisations and initiatives.

Conclusion: The pervasiveness of Web 2.0 technologies makes it inevitable that CSOs will have to restructure themselves to remain relevant.

\section{Introduction}

Even a cursory glance at newspapers, magazines or the television is sufficient for even a casual observer to notice the amount of reporting relating to Web 2.0 social media. Social media has broken stories about terrorist attacks in India, a shark attack off the West Coast of South Africa and was extensively exploited during the Arab Spring uprisings. It has become the constant companion of high-profile personalities and also of a large majority of the online population. Facebook, the world's largest online social network, has approximately one billion users, which is exceeded only by the populations of China and India. The microblogging site Twitter recorded tweets at the rate of 25088 per second during the screening of an anime movie in December 2011 (Akimoto 2011); social networking companies are amongst the fastest growing and social networking sites are regularly cited as the most searched for and viewed sites on the Internet (Most Popular Websites 2013).

The pervasiveness of social media has created a universal system of cooperation and collaboration encapsulated in a socially connected Web that supports, equally, all users' capacity to generate content. The ubiquitous nature of social media is what makes the Internet a strategic imperative in public-led socio-political campaigns. Social media has become an important tool in the arsenal of civil society organisations (CSOs) and indeed much of the success of a new resurgent civil society appears to be its ability to adopt and exploit new emerging technologies (Anheier, Glasius \& Kaldor 2001; Castells 2004).

This study follows that path as it tries to explore and explain why South African CSOs adopt social media and what perceptions have characterised the reason for adoption, be it from internal or external perspectives. The benefits of and barriers to adoption are also explored. The diffusion of innovations theory (Rogers 2003) underpins the study and provides a theoretical framework for the identification and understanding of the constructs that impact the adoption of Web 2.0 in CSOs. The diffusion framework argues that it is individual perception of the attributes of an innovation that affects adoption and not necessarily attributes defined by experts (Rogers 2003). 


\section{Background}

Civil society is those formal groups that facilitate the engagement of citizens in activities that exist and operate outside of government (Etling, Faris \& Palfrey 2010). From its Latin and Greek origins of societas civilis and politike koinona respectively, the term civil society has come to mean a 'political society' (Anheier et al. 2001), which emphasises the central role of citizens in institutional and policy development (Kaldor 2003). Civil society is made up of various global networks of organisations, movements, institutions and behaviours that exist between governments, the markets and the family (Glasius 2002; Kaldor 2003).

Van de Donk et al. (2004) point out that civil society communications have always been accompanied by a variety of media, including brochures, leaflets and newsletters, with the intention of gaining access to greater numbers of people within the organisation and in the public domain. A resurgence of civil society has been attributed to the sector's ability to exploit new emerging interactive technologies and its ability to adapt its communication and mobilisation strategies in the emerging technological paradigm (Anheier et al. 2001; Castells 2004). Communication, both internal and external, is core to the effectiveness of civil society; it is this centrality of communications that promotes the adoption of technology by CSOs. As Internet usage and mobile telephone usage increase, so does the ability of CSOs to develop their network structures and strengthen their capacity to connect with organisations around the world. It suggests that there is a virtual cycle between the network society and civil society.

\section{Research methodology}

A survey, which was designed to evaluate reasons why CSOs adopt Web 2.0 services, was conducted between May and June 2011. The survey was developed using the Google Docs ${ }^{\circledR}$ toolset, which created an online version of the survey. A Microsoft Word ${ }^{\circledR}$ version was also developed and respondents could complete either.

The population of South African CSOs is most comprehensively embodied in the Prodder database, which is maintained and administered by the non-government organisation, SANGONeT, whose stated function revolves around delivering Information and Communications Technology (ICT)-related services to the broader civil society sector (SANGONeT 2011). Organisational information (organisation name, website address, legal status, contact persons' email addresses and telephone numbers) was extracted from the database and validated to eliminate all organisations that either did not have an email address listed or did not have a valid email address (emails being returned as undeliverable). The eventual population of the study was the remaining 1712 organisations. The contact persons listed on the organisation's website were targeted by the survey and they were requested to either complete the survey or forward it to the relevant person in the organisation who could provide the requested information.
During the course of the survey, three reminders were sent: the first was sent a week after the survey was initially distributed, the second a week later and the third two weeks later. The final responses received included 105 online and 17 Microsoft Word ${ }^{\circledR}$ documents, giving a total of 122 , which was statistically adequate.

\section{What drives Web 2.0 adoption in South African civil service organisations \\ Internal reasons for Web 2.0 adoption amongst South African civil service organisations}

The internal reasons for the adoption of social media services in South African CSOs are illustrated in Figure 1. This analysis is in response to the question 'How important are Web 2.0 services to your organisation from an internal management perspective?' The responses were on a scale of one to five, with one signifying 'very unimportant' and five signifying 'very important'. The raw data was coded and aggregated and reported on as follows: one and two were grouped together as 'unimportant', three was coded as 'somewhat important' and four and five were aggregated as 'important'.

Over three-quarters $(76 \%)$ of CSOs believe that Web 2.0 is important firstly to ensure that the organisation becomes well known (visibility) and secondly as an avenue to access information (information intensity). The need to adapt to new technology was rated as important by $61.2 \%$ of respondents. The ability to reduce communication and backoffice costs was cited by $57 \%$ of respondents and, $56.2 \%$ cited the capacity of Web 2.0 to achieve organisational missions and goals. Web 2.0's usefulness in building expertise in ICTs was cited by $54.5 \%$ of respondents.

The power to gather information (or information intensity) is a strategic imperative for CSOs. The Internet has made countless information sources available, which has given CSOs a whole new world of intelligence and data-gathering capabilities (Surman \& Reilly 2003). Additionally, the new collaborative technologies that define Web 2.0 give CSOs the ability to tap into the zeitgeist of their supporters (Rigby 2008). Competition amongst CSOs makes it imperative for CSOs to remain relevant, which means being 'in sync' with their main constituency of supporters and donors.

In support of the need for organisations to become more visible (chosen by 76\% of respondents), Yang (2009) argues that online activists have begun to adopt marketing strategies to promote both their organisations and their causes. Activism no longer has the image of the scruffy children of the 1960s; rather, activists are now more likely to be fulltime employees of advocacy organisations, possibly with a scientific background and very likely with a post-graduate degree in the field of politics or business.

There was overwhelming positivity about Web 2.0's importance; only a small number of CSOs considered 
social media as unimportant from an internal management perspective. The largest of this minority, 24.8\%, consider social media as unimportant for capacity building. The factor analysis shows that there was no overlapping of variables, which indicates no mixing of factors for this question.

\section{External reasons for Web $\mathbf{2 . 0}$ adoption}

Civil society is made up of various global networks of organisations, movements, institutions and behaviours that exist between governments, the markets and the family (Glasius 2002; Kaldor 2003). They work at all levels of society and they work on the principle of broad involvement, which serves to develop the capacity for advocacy and activism at all levels (Keane 1995; Naidoo 2010). With the revolution in communication technologies transforming the world into the much-touted 'global village' (McLuhan 2011) social movements and social actions are also subject to the formal and informal rules of globalisation and are increasingly influenced by happenings in distant places (Della Porto \& Kriesi 2009). The implication of all of this is that CSOs must have a strong outward focus, which, as Edwards (2004) states, must create a space for citizens and other like-minded CSOs to influence state processes and policy.

The importance attached to social media from an external perspective is depicted in Figure 2. This analysis is in response to the question 'Indicate how important you think Web 2.0 services are to your organisation from an internal management perspective'. The responses were on a scale of one to five, with one signifying 'very unimportant' and five signifying 'very important'. The raw data was coded and aggregated and reported on as follows: one and two were grouped together as 'unimportant'; three was coded as 'somewhat important' and four and five were aggregated as 'important'.

Table 1 shows a cumulative percentage for the categories of 'somewhat unimportant' and 'important'.

A large number of the external reasons for Web 2.0 adoption were deemed important by a majority of respondents, including:

- To widen the influence on society $(86 \%)$.

- To provide knowledge to beneficiaries (86\%).

- To enable, empower and network $(90.9 \%)$.

- To cooperate and collaborate with other organisations $(87.6 \%)$.

- To disseminate information (88.4\%).

- To get a wider perspective and share knowledge (90.9\%).

- To gather information and knowledge (90\%).

- To reduce environmental waste and travel (85.1\%).

The majority of respondents were positive towards Web 2.0 as an external enabler. The largest negative factor relates to using Web 2.0 services to compete with other organisations: $28.1 \%$ of respondents rated this as unimportant. Only $47.9 \%$ of respondents saw Web 2.0's ability to accumulate bargaining power for advocacy as an important factor. When combined with the category 'somewhat important', this percentage rises to $72.7 \%$, with the remaining respondents (27.3\%) rating this as unimportant.

\section{Factor analysis}

Factor analysis revealed a grouping of social media services along two components; Table 2 illustrates component one

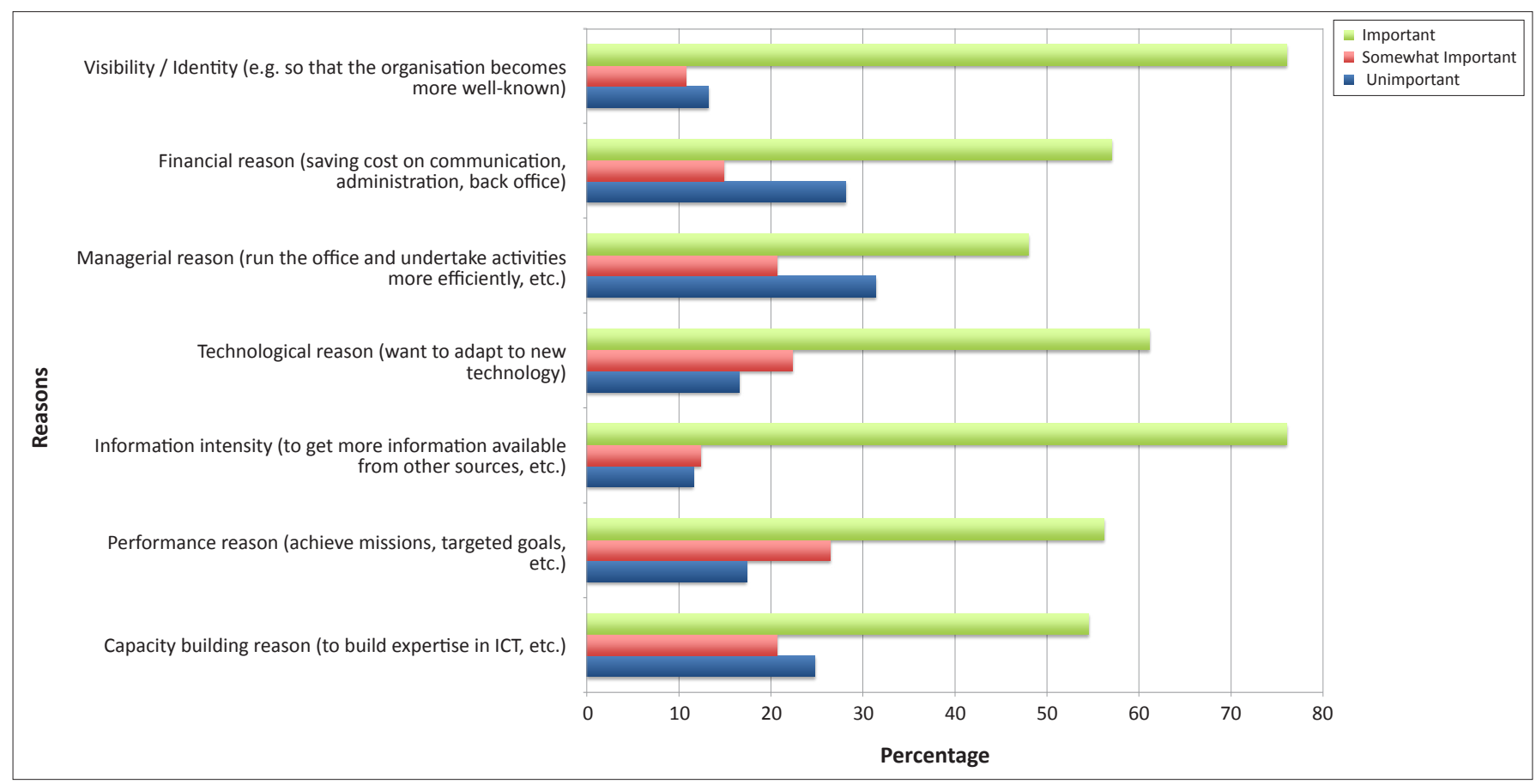

ICT, information and communications technology; PCs, personal computers.

FIGURE 1: Internal reasons for Web 2.0 adoption amongst South African civil society organisations. 


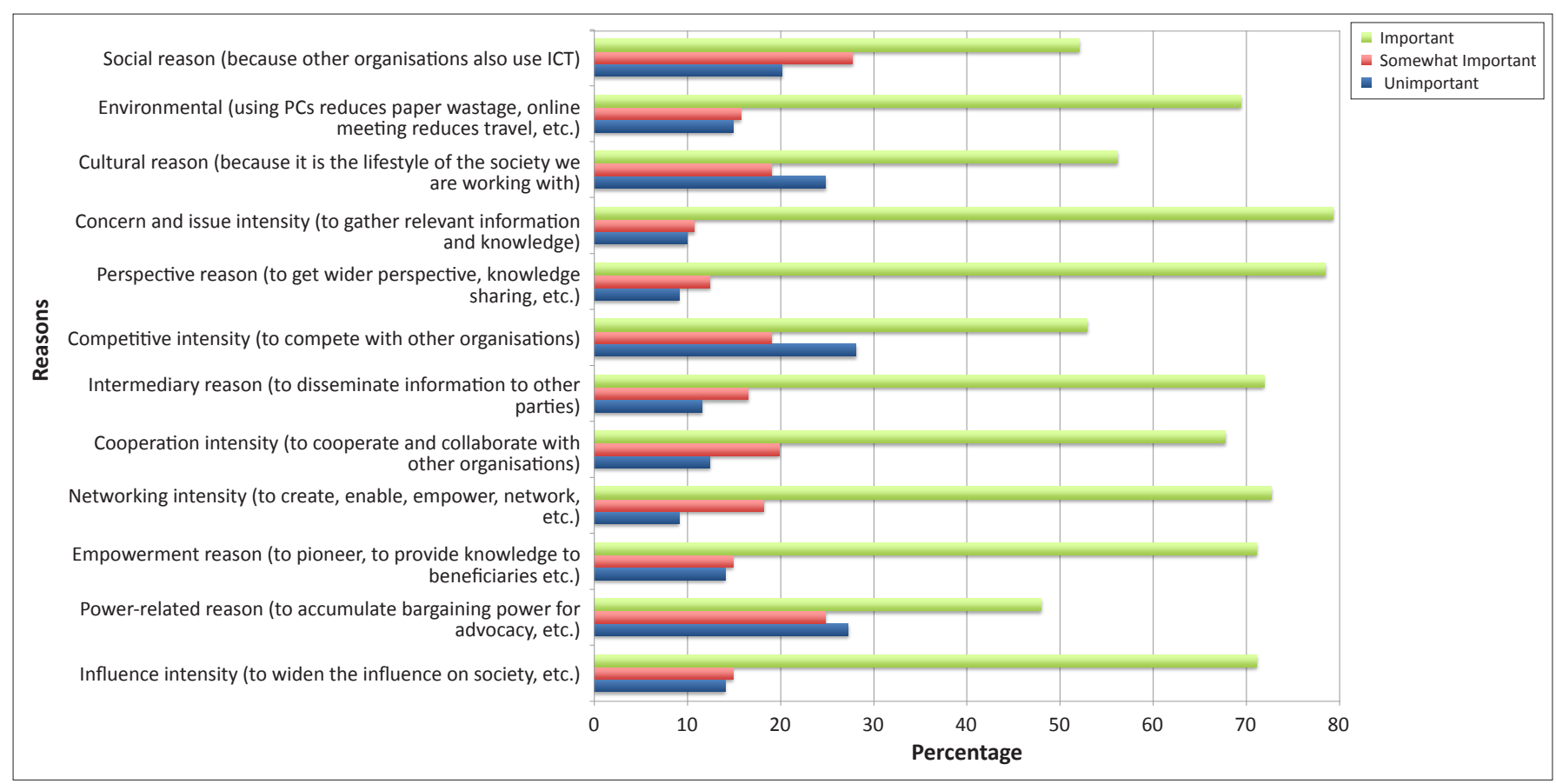

FIGURE 2: External reasons for Web 2.0 adoption in South African civil society organisations.

TABLE 1: External reasons for Web 2.0 adoption in South African civil society organisations.

\begin{tabular}{|c|c|c|}
\hline External reasons for Web 2.0 adoption & $\begin{array}{l}\text { Unimportant } \\
(\%)\end{array}$ & $\begin{array}{l}\text { Important } \\
(\%)\end{array}$ \\
\hline $\begin{array}{l}\text { Influence intensity (to widen the influence on } \\
\text { society, etc.) }\end{array}$ & 14.0 & 86.0 \\
\hline $\begin{array}{l}\text { Power-related reason (to accumulate bargaining } \\
\text { power for advocacy, etc.) }\end{array}$ & 27.3 & 72.7 \\
\hline $\begin{array}{l}\text { Empowerment reason (to pioneer, to provide } \\
\text { knowledge to beneficiaries, etc.) }\end{array}$ & 14.0 & 86.0 \\
\hline $\begin{array}{l}\text { Networking intensity (to create, enable, } \\
\text { empower, network, etc.) }\end{array}$ & 9.1 & 90.9 \\
\hline $\begin{array}{l}\text { Cooperation intensity (to cooperate and } \\
\text { collaborate with other organisations) }\end{array}$ & 12.4 & 87.6 \\
\hline $\begin{array}{l}\text { Intermediary reason (to disseminate } \\
\text { information to other parties) }\end{array}$ & 11.6 & 88.4 \\
\hline $\begin{array}{l}\text { Competitive intensity (to compete with other } \\
\text { organisations) }\end{array}$ & 28.1 & 71.9 \\
\hline $\begin{array}{l}\text { Perspective reason (to get wider perspective, } \\
\text { knowledge sharing, etc.) }\end{array}$ & 9.1 & 90.9 \\
\hline $\begin{array}{l}\text { Concern and issue intensity (to gather relevant } \\
\text { information and knowledge, etc.) }\end{array}$ & 9.9 & 90.0 \\
\hline $\begin{array}{l}\text { Cultural reason (because it is the lifestyle of the } \\
\text { society we are working with) }\end{array}$ & 24.8 & 75.2 \\
\hline $\begin{array}{l}\text { Environmental (using PCs reduces paper } \\
\text { wastage, online meeting reduces travel, etc.) }\end{array}$ & 14.9 & 85.1 \\
\hline $\begin{array}{l}\text { Social reason (because other organisations also } \\
\text { use ICT) }\end{array}$ & 20.2 & 79.8 \\
\hline
\end{tabular}

ICT, Information and Communications Technology.

and component two factors, cross-tabulated against the external reasons for social media adoption.

The component two factors with a value over 0.5 are social, environmental, cultural, concern and issue intensity, perspective and competitive intensity. The remaining reasons fall under component one.

The majority of the component one factors over 0.5 appear to relate to 'outward facing' reasons, for example dissemination of information, collaboration with other organisations, empowerment and networking, provision of knowledge, widened influence on society and accumulation of advocacy power. Tandon (2000) argues that emerging interactive technologies provide a communications platform between different types of local and international organisations that span a variety of interests, including religious, the labour movement, NGOs and diasporic groups, which provides some support for the 'outward facing' hypothesis that this section proposes.

In contrast, some of the component two factors over 0.5 are more organisationally 'inward facing,' for example: reducing wastage, increasing online meeting, reducing travel, gathering information, following trends set by other organisations and reflecting the society within which the organisation operates.

TABLE 2: Factor analysis.

\begin{tabular}{|c|c|c|}
\hline External reasons for social media adoption & Component 1 & Component 2 \\
\hline $\begin{array}{l}\text { Social reason (because other organisations also } \\
\text { use ICT) }\end{array}$ & 0.186 & 0.788 \\
\hline $\begin{array}{l}\text { Environmental (using PCs reduces paper } \\
\text { wastage, online meeting reduces travel, etc.) }\end{array}$ & 0.378 & 0.758 \\
\hline $\begin{array}{l}\text { Cultural reason (because it is the lifestyle of the } \\
\text { society we are working with) }\end{array}$ & 0.285 & 0.791 \\
\hline $\begin{array}{l}\text { Concern and issue intensity (to gather relevant } \\
\text { information and knowledge) }\end{array}$ & 0.540 & 0.690 \\
\hline $\begin{array}{l}\text { Perspective reason (to get wider perspective, } \\
\text { knowledge sharing, etc.) }\end{array}$ & 0.579 & 0.655 \\
\hline $\begin{array}{l}\text { Competitive intensity (to compete with other } \\
\text { organisations) }\end{array}$ & 0.325 & 0.681 \\
\hline $\begin{array}{l}\text { Intermediary reason (to disseminate information } \\
\text { to other parties) }\end{array}$ & 0.817 & 0.398 \\
\hline $\begin{array}{l}\text { Cooperation intensity (to cooperate and } \\
\text { collaborate with other organisations) }\end{array}$ & 0.798 & 0.387 \\
\hline $\begin{array}{l}\text { Networking intensity (to create, enable, } \\
\text { empower, network, etc.) }\end{array}$ & 0.796 & 0.347 \\
\hline $\begin{array}{l}\text { Empowerment reason (to pioneer, to provide } \\
\text { knowledge to beneficiaries, etc.) }\end{array}$ & 0.798 & 0.363 \\
\hline $\begin{array}{l}\text { Power-related reason (to accumulate bargaining } \\
\text { power for advocacy, etc.) }\end{array}$ & 0.780 & 0.192 \\
\hline $\begin{array}{l}\text { Influence intensity (to widen the influence on } \\
\text { society, etc.) }\end{array}$ & 0.828 & 0.351 \\
\hline
\end{tabular}

PCs, personal computers; ICT, Information and Communications Technology. 


\section{Functions of Web 2.0 usage in South African civil society}

The inescapability of social media has resulted in a significant increase in Internet-driven campaigning. These emerging technologies give CSOs the ability to advance their own agendas; organisational websites, blogs and email help in the mobilisation and coordination, not only of activists, but also of ordinary people who may have an interest in certain issues (Hara \& Shachaf 2008). In a Financial Times article, Gapper (2009) argues that the balance of power between governments and citizens has fundamentally changed due largely to the ubiquity of social media, which helps CSOs to recruit, communicate, campaign and fundraise. This section analyses the functions for which Web 2.0 is used in South African CSOs as illustrated in Figure 3. The question asked in which areas - marketing, market research, fundraising or campaigning - each of the listed Web 2.0 services was used.

Social networking is the most used service with just over $78 \%$ of respondents indicating their organisations adopting it for the following purposes: campaigning (25.2\%), fundraising $(7.8 \%)$, promotion of the brand $(40.9 \%)$ and market research $(4.3 \%)$. Perhaps surprisingly, fundraising via social networks garnered support from just $7.8 \%$ of CSOs. Photos and multimedia sharing and messenger applications followed in terms of usage with $59.6 \%$ and $58.4 \%$ of organisations using them for the one or more of the listed activities. The maintaining of organisational blogs (45.4\%), microblogging (45.8\%) and wikis (44.6\%) were the next most utilised services.

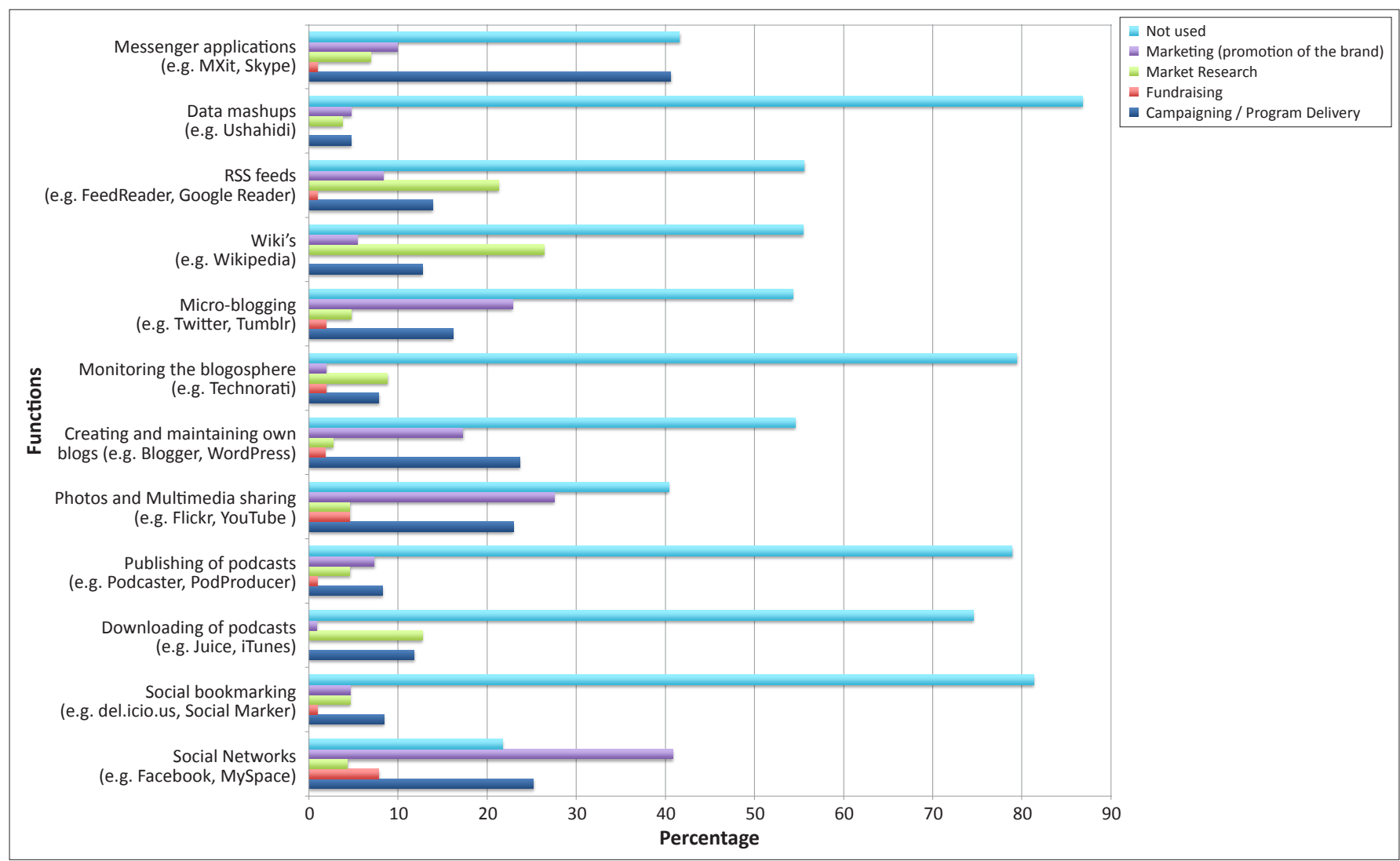

FIGURE 3: Functions of Web 2.0 usage in South African civil society organisations.

TABLE 3: Cumulative adoption versus cumulative areas of usage.

\begin{tabular}{|c|c|c|c|}
\hline Social media services & $\begin{array}{l}\text { Level of knowledge (fairly and } \\
\text { somewhat knowledgeable) (\%) }\end{array}$ & $\begin{array}{l}\text { Cumulative adoption - three } \\
\text { months or more ago (\%) }\end{array}$ & $\begin{array}{l}\text { Cumulative usage across all areas } \\
\text { (e.g. marketing, research, etc.) (\%) }\end{array}$ \\
\hline Social networks (e.g. Facebook, MySpace) & 81.0 & 82.4 & 78.2 \\
\hline Social bookmarking (e.g. del.icio.us, Social Marker) & 26.5 & 16.0 & 18.7 \\
\hline Publishing of podcasts (e.g. Podcaster, PodProducer) & - & 17.8 & 21.1 \\
\hline Photos and multimedia sharing (e.g. Flickr, YouTube) & 68.3 & 58.8 & 59.6 \\
\hline Creating and maintaining own blogs (e.g. Blogger, WordPress) & 46.2 & 44.9 & 45.4 \\
\hline Microblogging (e.g. Twitter, Tumblr) & 46.3 & 43.7 & 45.8 \\
\hline Wikis (e.g. Wikipedia) & 59.5 & 42.4 & 44.6 \\
\hline RSS feeds (e.g. FeedReader, Google Reader) & 52.1 & 44.6 & 30.5 \\
\hline Data mashups (e.g. Ushahidi) & 16.6 & 11.0 & 13.2 \\
\hline Messenger applications (e.g. MXit, Skype) & 66.9 & 63.0 & 58.4 \\
\hline
\end{tabular}


Table 3 summarises data on levels of knowledge about social media services, adoption rates and data with respect to the functions of social media usage.

As can be expected, there is a high degree of correlation between levels of knowledge, adoption and usage. For example, $81 \%$ of respondents indicated being knowledgeable about social networks; $82.4 \%$ of organisations had adopted social networks at least more than three months ago, with $78.2 \%$ using them for either campaigning and program delivery, fundraising, market research or promotion of the brand. Similar patterns emerged for all of the other services. Internationally, CSOs are using social networks as a tool for program delivery, marketing, customer support, fundraising and market research, and looking forward, the goal of these CSOs is to use social networking sites to engage members and grow membership (NTEN 2010).

\section{Benefits and barriers}

This section analyses the benefits of and barriers to Web 2.0 deployment in South African civil society. The questions from the survey that informed this analysis are: 'In what way has your organisation benefited from its use of Web 2.0 social media?' and 'What difficulties has your organisation experienced in deploying Web 2.0 services?'.

\section{Benefits of social media adoption}

Social media provide a cheap, flexible, ubiquitous and distributed medium that has given opposition movements the ability to mount challenges on various fronts. Shirky (2010) argues that one way to look at social media is as a longterm tool that has the ability to strengthen civil society and to provide alternate discourses in the public sphere. Figure 4 illustrates the benefits experienced by CSOs with regard to social media services.

The biggest benefits of social media to South African CSOs are performance reasons $(55.5 \%)$, building wider networks $(52.5 \%)$, and better communications of ideas with other organisations (48.3\%). The common theme that emerges from these responses is one of communication and networking, which, taken together, have an average of $52 \%$. Fundraising (32.8\%) and opinion building (38.1\%) were the other areas where some benefit was realised. Social media does not assist organisations to save costs or assist in the management of the with $41.9 \%$ indicating little benefit, or save costs with $43.6 \%$ indicating little benefit.

Paradoxically, whilst respondents see the benefit of social media in building wider networks with other organisations $(52.5 \%)$, this does not extend to actually undertaking collaborative projects with other CSOs $(40.2 \%$ of respondents saw little benefit in this). There were an almost equal proportion of respondents that saw either some benefit or little benefit in using social media for campaigning and opinion building (38.1\% vs $35.6 \%)$. The factor analysis shows that there was no overlapping of variables, which indicates no mixing of factors for this question.

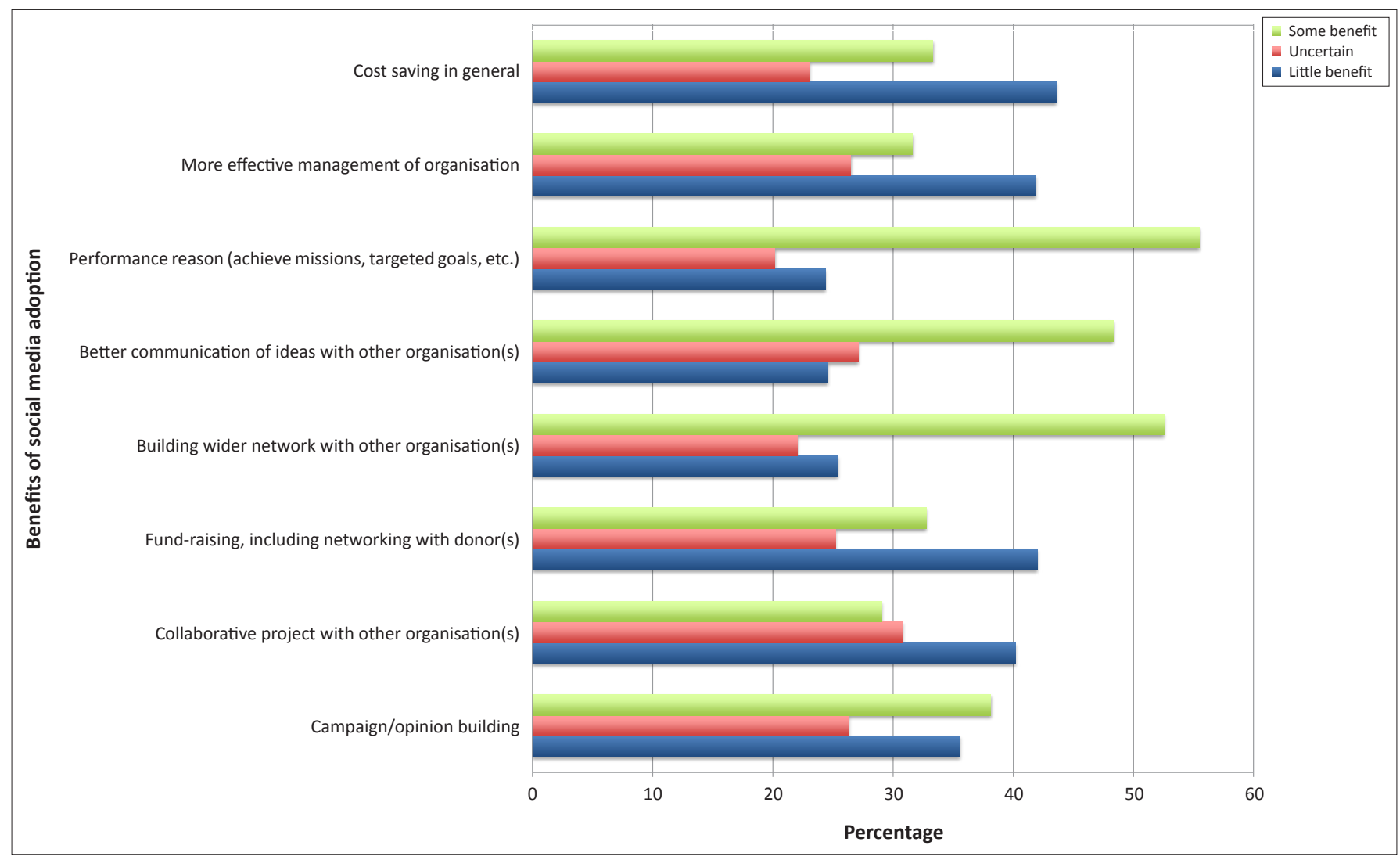

FIGURE 4: Benefits of social media adoption. 
In the responses to the usage of social media, just under $8 \%$ of respondents indicated that they used social media for fundraising, whilst in response to the benefits of social media, $32.8 \%$ of respondents believed that social media has 'some benefit' in respect of fundraising. This is a case of expected benefits not equating to actual usage. One possible reason for this is that whilst social media may be a viable channel for fundraising, there is still a lot of hesitancy amongst South Africans in general for online financial transacting. In a study conducted by MasterCard (Polity.org.za 2012), 51\% of South Africa's online population conduct online financial transactions. Of the people who have access to the Internet but who do not conduct online transactions, just over $50 \%$ cite online security as the reason for not transacting online. Fundraising online requires transmitting personal financial information and would be subject to the same security concerns cited above.

\section{Barriers to the deployment of social media}

Many CSOs, due to their reliance on external funding, exist in an environment of constant economic uncertainty. Additionally, emerging technologies change constantly, which in turn means that engaging with these technologies becomes an ongoing process of discovery and learning. These technologies also bring about a permanent change to the way the organisation communicates and collaborates. All of these factors make it difficult for these organisations to effectively run campaigns in the face of a lack of information, tools and skills.

In a survey conducted by the Nonprofit Technology Network (NTEN 2009), it was reported that CSOs required more time and more trained staff in order to improve their use of social networks. A large percentage of respondents (74.1\%) indicated a need to know 'which tools are useful for what' and $44.4 \%$ indicated a need for training in how these tools work.

This section analyses the barriers to the deployment of social media in South African CSOs and the responses are illustrated in Table 4.

Thirty-six respondents (or 30\%) cite the 'lack of skilled human resources' as the biggest barrier to deploying social media. The only other significant barrier identified was a 'lack of money', which was chosen by 19 (16\%) organisations. The remaining barriers that were listed in the survey were insignificantly represented in the sample.

TABLE 4: Barriers to deploying social media.

\begin{tabular}{lll}
\hline Barriers to the deployment of social media & $\boldsymbol{f}$ & $\mathbf{\%}$ \\
\hline Lack of infrastructure & 6 & 5.0 \\
Lack of skilled human resources; Lack of infrastructure & 6 & 5.0 \\
Lack of money; Lack of skilled human resources & 7 & 5.9 \\
Lack of money; Lack of skilled human resources;- Lack of infrastructure & 7 & 5.9 \\
Internal policy, management & 8 & 6.7 \\
Lack of money & 19 & 16.0 \\
Lack of skilled human resources & 36 & 30.3 \\
\hline
\end{tabular}

$f$, frequency.

\section{Perceived attributes and attitudes towards Web 2.0}

This section looks at the results of the attitudes and perceptions of CSO respondents towards Web 2.0 social media.

\section{Perceptions on the use of Web 2.0 in South African civil society}

Figure 5 interrogates the responses to the question relating to the impact of social media on CSOs. Respondent perceptions of social media were as follows:

- Has a positive influence on the organisations relationships with other CSOs (52.9\%).

- Helps the organisations gain a wider perspective towards issues and concerns (55.5\%).

- Increases dialogue with supporters (54.6\%).

The ratio of agreement to disagreement for the above statements is approximately two to one. The statements that relate to gaining 'a wider perspective towards issues and concerns' and 'increasing dialogue with supporters' are related to the benefits experienced by CSOs, that is: better communication of ideas with the public, better communication of ideas with other organisations and the ability to build wider networks with other organisations.

The first statement, that social media 'has assisted in the performance of the internal management of the organisation', reflects overall neutrality: there are as many respondents who agreed with the statement as there are those who disagreed. The factor analysis shows that there was no overlapping of variables, which indicates no mixing of factors for this question.

Increased dialogue with supporters is an important consideration for CSOs. The Internet, and in particular the World Wide Web, has given civil society more power to craft their public image thereby 'altering the landscape of protest' (Owens \& Palmer 2003). Social movements also run the risk of alienating their supporter base by defining campaigns based on what will resonate with the media and other global publics (Mann 2008).

\section{Impact of Web 2.0}

This section establishes the areas within which civil society operates and where social media has had a positive impact (Figure 6).

All of the statements have positive responses except for those relating to internal staff development. However, the strength of the agreement is moderate when compared to the (high) levels of uncertainty for each statement. For example, comparing levels of agreement to levels of being unsure reveals the following: $55 \%$ versus $30 \%$ for development initiatives, $53.8 \%$ versus $28.6 \%$ for training and $57.5 \%$ versus $30 \%$ for advocacy. Internal staff development had an equal 


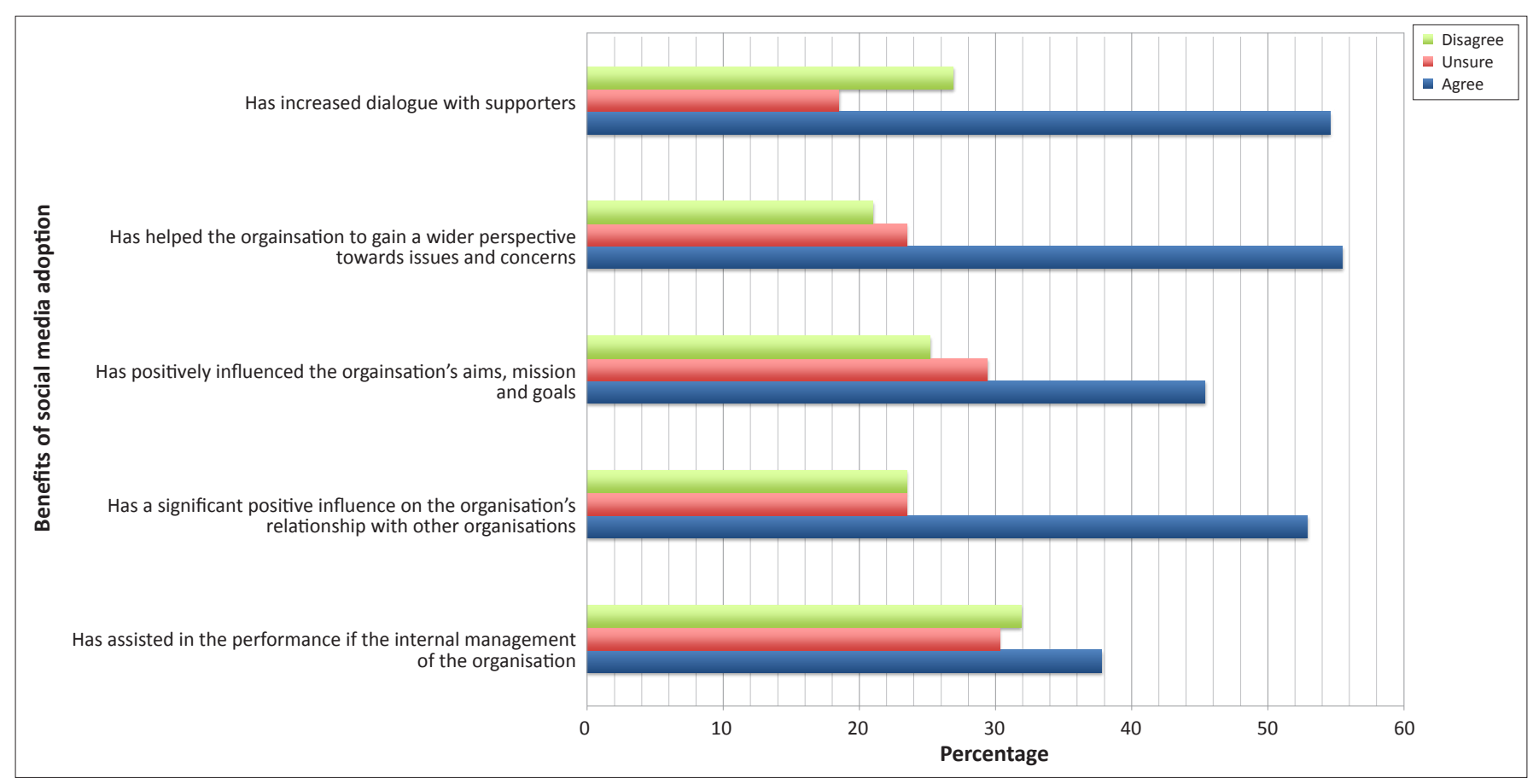

FIGURE 5: Perceptions on the use of Web 2.0.

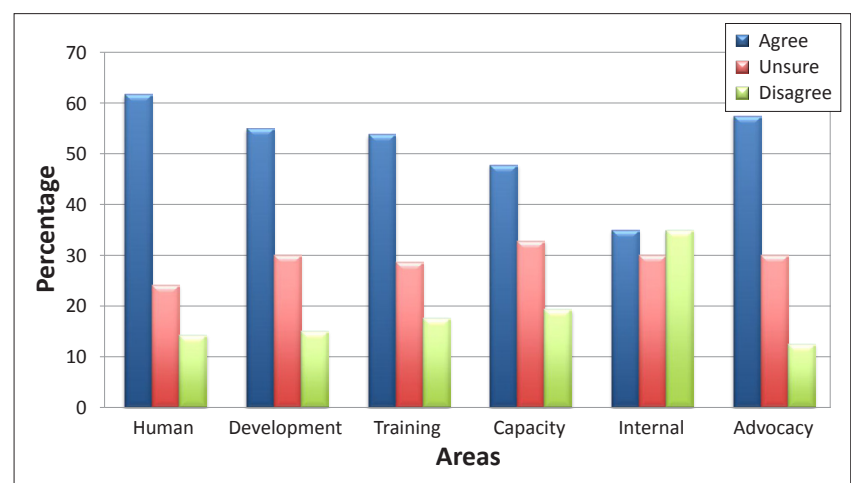

FIGURE 6: Areas of impact of Web 2.0.

split between those who agreed and those who disagreed. The factor analysis shows that there was no overlapping of variables, which indicates no mixing of factors for this question.

If social networking sites are a typical example of a Web 2.0 service, as argued by Memmi (2010), then, internationally, civil society sentiment towards social media is very positive: four out of five $(80 \%)$ of organisations indicate that they find their social networking efforts valuable (NTEN 2010).

\section{Conclusion}

Two surveys (one in 2007 and the other in 2009) into the adoption of ICTs by CSOs have shown that South African civil society has, by and large, enthusiastically embraced technology and that ICTs have become integral to civil society's effective functioning (World Wide Worx 2009). With regard to social media services, internal reasons for adoption coalesce around organisational visibility and access to information. External reasons focus on organisations needing to become more relevant and more connected to like- minded organisations and initiatives. The main reason for the deployment of social media by CSOs mirrors the external reason for adoption: promotion of the organisational brand.

The adopting of emerging technologies and innovation, and the planning and management thereof is almost always a complex and complicated exercise; new sets of knowledge competencies have to merge with the organisation's existing capabilities. In the case of civil society, add to this mix the emergence of new flexible and adaptable online CSOs all vying for the same set of supporters and you have a situation that makes it imperative for organisations to re-evaluate the very core of their values. Whilst social media adoption patterns, reasons for adoption and benefits, and barriers experienced are only just beginning to be explored, what is certain is that the pervasiveness of these technologies ensures the inevitability that organisations will have to restructure and reorientate themselves to remain relevant in a new emerging technology paradigm.

\section{Acknowledgements Competing interests}

The authors declare that they have no financial or personal relationship(s) that may have inappropriately influenced them in writing this article.

\section{Authors' contributions}

M.S.M. (University of KwaZulu-Natal) supervised K.P. (University of KwaZulu-Natal) for his PhD.

\section{References}

Akimoto, A. 2011, 'The year when Japan went global over social networking', The Japan Times, viewed 28 December 2011, from http://www.japantimes.co.jp/text/ nc20111221aa.html 
Anheier, H., Glasius, M. \& Kaldor, M., 2001, 'Introducing global civil society', in H. Anheier, M. Glasius \& M. Kaldor (eds.), Global civil society, pp. 3-22, Oxford Anheier, M. Glasius \&
University Press, Oxford.

Castells, M., 2004, The information age: Economy, society and culture, vol. II, Blackwell Publishing, New York, NY.

Della Porto, D. \& Kriesi, H., 2009, 'Social movements in a globalizing world: An introduction', in D. Della Porto, H. Kriesi \& D. Rucht (eds.), Social movements in a globalizing world, pp. 3-22, Palgrave Macmillan, New York.

Edwards, M., 2004, Civil society, Cambridge Polity, Cambridge.

Etling, B., Faris, R. \& Palfrey, J., 2010, 'Political change in the digital age: The fragility and promise of online organizing', SAIS Review 30(2), 37-49.

Gapper, J., 2009, 'Technology is for revolution (and repression)', Financial Times, viewed 27 July 2011, from http://www.ft.com/intl/cms/s/0/4386d188-5cfe-11de9d42-00144feabdc0.html\#axzz1qyLdo6BA

Glasius, M., 2002, Global civil society yearbook 2002, London School of Economics, London.

Hara, N. \& Shachaf, P., 2008, 'Online peace movement organizations: A comparative analysis', in I. Chen \& T. Kidd (eds.), Social information technology: Connection society and cultural issues, pp. 52-67, Idea Group, Hershey.

Kaldor, M., 2003, 'Civil society and accountability', Journal of Human Development $4(1), 5-27$.

Keane, J., 1995, 'Structural transformations of the public sphere', Communication Review 1(1), 1-22.

McLuhan, M., 2011, The Gutenberg galaxy - The making of typographic man, University of Toronto Press, Toronto.

Mann, A., 2008, 'Spaces for talk: Information and communication technologies (ICTS) and genuine dialogue in an international advocacy movement', Asian Socia Science 4(10), 3-13.

Memmi, D., 2010, 'Sociology of virtual communities and social software design', in S. Murugesan (ed.), Web 2.0, 3.0, and X.O: Technologies, business, and socia applications, vol. II, pp. 790-803, Information Science Reference, New York.

Most Popular Websites, 2013, '25 March 25', in Most popular, viewed 25 March 2012, from http://mostpopularwebsites.net/
Naidoo, K., 2010, 'Boiling point: Can citizen action save the world', Development Dialogue 54, 1-200.

Nonprofit Technology Network (NTEN), 2009, Common knowledge and the port (2009) Nonprofit social network survey', viewed 30 July, 2009, from http://www. nonprofitsocialnetworksurvey. com

NTEN, 2010, Nonprofit social network benchmark report, viewed 01 April 2011, from http://www.nten.org/blog/2010/04/20/2010-nonprofit-social-networkbenchmark-report

Owens, L. \& Palmer, L., 2003, 'Making the news: Anarchist counter-public relations on the World Wide Web', Critical Studies in Media Communication 20(4), 335361 .

Polity.org.za, 2012, MasterCard, viewed 12 January 2012, from http://www.polity. org.za/article/south-africas-online-shopping-on-the-rise-2011-09-26

Rigby, B., 2008, Mobilizing generation 2.0: A practical guide to using Web 2.0, Jossey-Bass, San Francisco.

Rogers, E.M., 2003, Diffusion of innovations, The Free Press, A division of Simon \& Schuster, New York.

SANGONeT, 2011, About SANGONeT, viewed 31 October 2011, from http://www. ngopulse.org/about

Shirky, C., 2010, SXSW: South by southwest, viewed 15 March 2011, from http:// schedule.sxsw.com/2011/events/event_IAP000246

Surman, M. \& Reilly, K., 2003, Appropriating the Internet for social change: Towards the strategic use of networked technologies by transnational civil society organizations, Social Sciences Research Council, Information Technology and International Cooperation Program, New York.

Tandon, R., 2000, 'Riding high or nosediving: Development NGOs in the new millennium', Development in Practice 10(3/4), 319-329.

Van de Donk, W., Loader, B., Nixon, P. \& Rucht, D., 2004, 'Social movements and ICTs', in W. van de Donk, B. Loader, P. Nixon \& D. Rucht (eds.), Cyberprotest: New media, citizens and social movements, pp. 1-25, Routledge, London.

World Wide Worx, 2009, The state of ICTs in the South African NGO sector, Author, Johannesburg.

Yang, G., 2009, The power of the Internet in China, Columbia University Press, New 